\title{
The Assessment of AquaCrop Model in Predicting Rice Genotypes Grain and Biological Yield under Water Management Conditions
}

\author{
Sh Roshani' ${ }^{1}$, M.H. Rashed Mohassel ${ }^{2}$, R. Sadrabadi Haghighi ${ }^{1 *}$, E. Amiri ${ }^{3}$ \\ 'Department of Agricultural Science, Mashhad Branch, Islamic Azad University, Mashhad, Iran \\ ${ }^{2}$ Department of Agronomy, Faculty of Agriculture, Ferdowsi University of Mashhad Iran, Mashhad, Iran \\ ${ }^{3}$ Department of Water Engineering, Lahijan Branch, Islamic Azad University, Lahijan, Iran
}

Received: 23 February 2020

Accepted: 2 August 2020

\begin{abstract}
The present study was conducted to assess the ability of AquaCrop model in predicting genotypes of rice genotypes grain and biological yield in water management on Rice Research Institute of Iran, for two consecutive years of 2017 and 2018. The type of experiment was split plot based on randomized complete block design with three replications per treatment. The main plot included of irrigation treatment at four levels, (flood irrigation, 5, 8 and 11 days intervals) and sub plot, included of Ali kazemi, Dorfak and Bahar rice genotypes. Evaluation simulated and measured grain yield and biological yield by adjusted coefficient of correlation and by absolute and normalized root mean square errors (RMSEn). The results indicated, the RMSEn for predicting the amounts of grain yield in validation and calibration phases for Ali kazemi, Dorfak and Bahar was assessed in the range of 6 to 8 and 8 to 9 percent respectively and the RMSEn for predicting amounts of biological yield in validation and calibration for rice genotypes was assessed in the range of 3 to 13 and 7 to $15 \%$ respectively. The results showed that the AquaCrop model had acceptable accuracy in predicting grain yield and biological yield of the crop.
\end{abstract}

Keywords: calibration, model, rice cultivars, simulation, validation

\section{Introduction}

Rice originated from Southern Asia, is an important crop in most Asian countries, including Iran [1]. It supplies more than the one fifth calories needed per capita [2]. With acreage of 160 million hectares worldwide it produces 700 to 750 million tons of

*e-mail: rsadrabadi@mshdiau.ac.ir rice [3]. Rice is one of the main crop in Iran with 600 thousand hectares under cultivation. Meanwhile, Guilan and Mazandaran province with $70 \%$ of rice growing area are the main regions of rice producing in Iran [4]. According to IRRI statistics, it is estimated by 2020 the population of Iran will be around 130 million, the rice annual consumption is estimated $33 \mathrm{~kg}$, therefore, the need to this crop will be around 4 million tons. Therefore, providing the future demand of rice in Iran require improving rice product qualitavely and quantitively [5]. 
Nowadays, one- third of farms in the world faces water shortage and it is expected that this process reaches to two- third by 2025 [6, 7]. Drought is the main limiting factor for crop producing in the developing countries and most part of the world [8], that is exacerbating with climate changing situations $[6,7]$. More than $80 \%$ of freshwater resources in Asia are used for irrigation purposes and about half of this amount is used for irrigating rice plantation [9]. Water is the most limiting factor for sustainable production in temperate rice regions. Approximately $75 \%$ of the world's rice is produced from irrigated rice paddies [10], make up about $50 \%$ of all paddy fields in the world [11].

In Guilan province, rice is usually grown in nurseries and transplanted under flood irrigation situations. Sepidrood river that is formed by joining two Ghazalozan and Shahrood (with more than one billion cubic meters water supply per year) is the main source of irrigation in Guilan province [12]. Because of the presence of several dams and reservoirs along Sepidrood river (specially Ghazalozan catchment) [13], along with significant decrease of water entrance volume of Sepidrood, the quality and quantity of water has been decreased. Therefore, regarding the industrial use of water and water for drinking and agricultural purposes, the amount of water for rice production is being reduced and threaten the rice plantation [12].

One of the most effective methods for managing rice production is the use of crop growth models. This can be accomplished by simulating the grain production process using computer-based mathematical equations and by considering highly effective variables on yield. The model is a simple shape of a system and simulation is the studying of system behavior by the help of the model. The simulating models of crops are useful equipment for realizing the biophysical processes of soil-plant-atmosphere [14]. These models simulate climate changes, plants genotype characteristics, soil characteristics and managing factors such as irrigation on plant growth. The limited number of effective factors on plant growth in a special area and one growing season is a common experiment for farms evaluation. Simulating models not only assess the effect of climate and management varieties on plant growth but to some degree may be used for implementing achieved data to other regions and areas as well [15]. Simulating models may use for quantifying the variation of yield at various levels of management [16]. The yield quality of crops simulating models depends on accessibility of necessary inputs for implementing these models. The simulating models of crops is a useful mean for realizing biophysical processes dominating on soil-plant-atmospheric system [14].

The AquaCrop model was introduced recently by FAO, it considers the effect of water stress on production of dry materials and the yield of plant grain on growth period based on humidity of soil. In comparison with other simulation models, it requires limited number of parameters and data for simulating the plant reaction to water and it is being used for most of the plants and crops. These parameters are usually determined directly and using this model is simple and accurate [17]. In AquaCrop model, the input data are saved in climate, plant, soil and management and can be easily changed by the user. This model has great abilities and can investigate the water stress effects in specific time of growing season [18]. Malik et al. tried to investigate the ability of AquaCrop model in simulating of biological yield and yield of sugar beet root in various irrigations and farming management production in a semiarid region in Pakistan. He concluded the use of AquaCrop model is a useful method of water management in sugar beet plantation in semiarid regions of Pakistan [19].

Akumaga et al. in testing and evaluating the AquaCrop model tried to demonstrate the simulation of grain yield from weak, middle to very good indices using nitrogen levels in corn in Nigeria. Their results indicated that the RMSE was between $8 \%$ (excellent) and $17 \%$ (good) [20]. Montoya et al. (2016) in validating and calibrating of the AquaCrop model for simulating the potato yield under four irrigation regimes $(120 \%$, $100 \%, 80 \%, 60 \%$ of required water), observed that the error was less than ten percent in the calibration year and the error more than ten percent in the validation year. The increasing of error in this experiment was due to incorrect estimating of harvesting index with the increase of heat stress in the flower formation stage [21].

Toumi et al. could find water utilization and grain yield after validating and calibrating of the AquaCrop model for winter wheat under several irrigation management practices and appropriate plantation date [22].

Mabhaudhi et al. (2014) assessed one of the tropical plants named Taro in the semiarid region of Southern Africa with use AquaCrop model and estimated the biological yield with coefficient of determination of 0.99 and RMSE of 1.74 ton in hectare [23].

Kumar et al. (2014) after assessing the AquaCrop model in Delhi (India) for four genotypes of wheat (three saline tolerant genotypes and one saline sensitive genotype) and four levels of water salinities for irrigation recommended that this model has acceptable accuracy in simulating crop and biological yield [24].

Khalili et al. (2014) in simulating the rain fed wheat yield with AquaCrop model in Iran demonstrated that this model has great potential for of crop yield with high accuracy and coefficient of determination, RMSEn and standard between the yield of assessed and simulated grains were calculated $0.86,0.062$ and 5.235 respectively [25].

This study was conducted with the goal to assessing the AquaCrop model in simulating various growth parameters with the results of under irrigation farms on grain yield, biological yield and yield elements of all genotypes of Guilan province rice in northern Iran. 


\section{Materials and Methods}

\section{Field Experiment}

The present study was conducted during growing season of 2017 and 2018 on Rice Research Institute of Iran with latitude of $37^{\circ} 12^{\prime} 19^{\prime \prime} \mathrm{N}$, longitude $49^{\circ} 38^{\prime} 28^{\prime \prime} \mathrm{E}$ and altitude of 7 meter below the sea level in Rasht. The experimental design was split plot based on randomized complete block arrangement and three replications per treatment. The main factor was irrigation at four levels (flood irrigation and irrigation with intervals of 5, 8, and 11 days) and sub plots were rice genotype at three levels (Ali kazemi, Dorfak and Bahar). After transferring genotypes to the main land, the plots were kept in flood irrigation for 10 days for complete of rice establishment. The water management was performed on the plots using the volume counters to assess the amount of water volume. Some physical properties of experimental field are shows in Table 1. The grain yield and biological yield were measured by removing 5 square meters in the middle of each plot. The required climate information was gathered by using Rasht synoptic weather station. Transpiration and evapotranspiration were assessed also by Mantis penman FAO method and by the use of $\mathrm{ET}_{\mathrm{O}}$ calculator [26].

The AquaCrop model describes soil-plantatmosphere parameters. This model results from Doorenbos and Kassame equation in which relative evapotranspiration is the basis of yield assessing [27].

$$
\frac{Y_{\mathrm{X}}-\mathrm{Y}_{\mathrm{a}}}{\mathrm{Y}_{\mathrm{X}}}=\mathrm{k}_{\mathrm{y}} \frac{\mathrm{ET}_{\mathrm{x}}-\mathrm{ET}_{\mathrm{a}}}{\mathrm{ET}_{\mathrm{x}}}
$$

...where, $\mathrm{Y}_{\mathrm{x}}=$ the maximum yield, $\mathrm{Y}_{\mathrm{a}}=$ the actual yield, $\mathrm{ET}_{\mathrm{x}}=$ the maximum transpiration, $\mathrm{ET}_{\mathrm{a}}=$ the actual evapotranspiration and $\mathrm{K}_{\mathrm{y}}=$ the coefficient of proportion between relative yield decrease and evapotranspiration decrease. In fact, the AquaCrop, a simple vegetation growth and aging model has been developed by separating evaporation from transpiration as the basis to estimate transpiration separate from evaporation, final yield simulation $(\mathrm{Y})$ as a function of the final biological yield (B) and harvest index (HI) and the separation of effects of water stress on four components of canopy, aging, stomata closure, transpiration decrease and harvest index.

Dividing ET into $\operatorname{Tr}$ and E prevents non-productive use of water through E, especially when vegetation conditions are not complete. Daily transpiration $\left(\operatorname{Tr}_{\mathrm{i}}\right)$ that has been normalized using daily $\mathrm{ET}_{\mathrm{o}}$ and water productivity (WP) using the need for evapotranspiration and carbon dioxide concentration became biological weight of the plant shoot [28].

Equation (2) represents the followings:

$$
B_{i}=\mathrm{WP}^{*} \times\left[\frac{\mathrm{Tr}_{\mathrm{i}}}{\mathrm{ET}_{0_{\mathrm{i}}}}\right]
$$

In which, $B_{i}$ is the plant shoot weight in day $\mathrm{i}$ $\left(\mathrm{g} \mathrm{m}^{-2}\right), \operatorname{Tr}_{\mathrm{i}}$ is the daily transpiration $(\mathrm{mm}), \mathrm{ET}_{\mathrm{oi}}$ refer to plant transpiration evapotranspiration in day $\mathrm{i}(\mathrm{mm})$, WP* is normal water productivity $\left(\mathrm{g} \mathrm{m}^{-2}\right)$ and its value under the same climatic conditions is constant and equal for $\mathrm{C}_{3}$ and $\mathrm{C}_{4}$ plants. Normal water productivity for $\mathrm{C} 4$ plants like corn is changing between 28 to $33\left(\mathrm{~g} \mathrm{~m}^{-2}\right)$.

\section{Result Assessment of AquaCrop Model}

For statistical assessment of simulating results, t-test and following statistical variables were used [29].

$$
\begin{gathered}
\text { RMSE }=\left(\sum_{I=1}^{n}\left(P_{i}-O_{i}\right)^{2} / n\right)^{0.5} \\
\operatorname{RMSE}_{\mathrm{n}}=100\left(\sum_{I=1}^{n}\left(P_{i}-O_{i}\right)^{2} / n\right)^{0.5} / O_{\text {mean }}
\end{gathered}
$$

...where,

$\mathrm{P}_{\mathrm{i}}=$ Simulating amount of value

$\mathrm{O}_{\mathrm{i}}=$ Actual assessing amount of value

$\mathrm{n}=$ Actual assessing number of values

$\mathrm{O}$ mean $=$ Mean assessing amount of value

\begin{tabular}{|c|c|c|c|c|c|c|c|c|}
\hline \multirow{2}{*}{$\begin{array}{c}\mathrm{K}_{\mathrm{S}} \\
\left(\text { day }^{-1}\right)\end{array}$} & \multicolumn{3}{|c|}{ Moisture content (vol \%) } & \multirow{2}{*}{$\begin{array}{l}\text { Bulk Density } \\
\qquad\left(\mathrm{g} \mathrm{cm}^{-1}\right)\end{array}$} & \multirow{2}{*}{ Clay $(\%)$} & \multirow{2}{*}{ Loam (\%) } & \multirow{2}{*}{ Sand $(\%)$} & \multirow{2}{*}{ Depth $(\mathrm{cm})$} \\
\hline & $\theta_{\mathrm{SAT}}(-)$ & $\theta_{\mathrm{FC}}(-)$ & $\theta_{\mathrm{PWP}}(-)$ & & & & & \\
\hline 575 & 0.65 & 0.40 & 0.27 & 1.10 & 47 & 39 & 14 & $0-10$ \\
\hline 308 & 0.62 & 0.40 & 0.30 & 1.20 & 44 & 39 & 17 & $10-20$ \\
\hline 4 & 0.62 & 0.41 & 0.30 & 1.32 & 47 & 44 & 9 & $20-30$ \\
\hline 114 & 0.60 & 0.42 & 0.30 & 1.31 & 47 & 42 & 11 & $30-40$ \\
\hline
\end{tabular}

RMSE $=$ Root Mean Square Error

RMSEn $=$ Normalized Root Mean Square Error

Table 1. Soil physical properties of experiment field.

Abbreviations are: $\mathrm{Ks}=$ saturated hydraulic conductivity; $\theta_{\mathrm{SAT}}=$ saturated volumetric water content; $\theta_{\mathrm{FC}}=$ field capacity volumetric water content; $\theta_{\mathrm{PWP}}$ permanent wilting point. 
Table 2. Evaluating the AquaCrop model simulation results under calibration conditions, 2017.

\begin{tabular}{|c|c|c|c|c|c|c|c|c|}
\hline Genotypes & Genotypes & $\mathrm{N}$ & $\mathrm{X}_{\mathrm{obs}}$ & $\mathrm{X}_{\text {sim }}$ & $\mathrm{RMSE}$ & $\mathrm{RMSE}_{\mathrm{n}}(\%)$ & $\mathrm{P}(\mathrm{t})$ & $\mathrm{R}^{2}$ \\
\hline \multirow{3}{*}{ Ali kazemi } & Grain yield & 4 & 3691 & 4214 & 267 & 7 & 0.17 & 0.93 \\
\cline { 2 - 11 } & Biological yield & 4 & 9748 & 9757 & 294 & 3 & 0.49 & 0.98 \\
\hline \multirow{3}{*}{ Dorfak } & Grain yield & 4 & 5281 & 5482 & 311 & 6 & 0.38 & 0.94 \\
\cline { 2 - 11 } & Biological yield & 4 & 12642 & 11372 & 1612 & 13 & 0.14 & 0.86 \\
\hline \multirow{2}{*}{ Bahar } & Grain yield & 4 & 5917 & 5311 & 484 & 8 & 0.39 & 0.93 \\
\cline { 2 - 11 } & Biological yield & 4 & 14505 & 11375 & 1574 & 11 & 0.25 & 0.97 \\
\hline
\end{tabular}

$\mathrm{X}_{\mathrm{obs}}$ : mean measured values, $\mathrm{X}_{\text {sim }}$ : mean simulated values, RMSE: Root Mean Squared Error, RMSE $\mathrm{n}_{\mathrm{n}}$ Normalized Root Mean Squares Error

In this method the simulation considers excellent with a RMSEn of less than $10 \%$, good if the RMSEn is greater than 10 and less than $20 \%$, fair if the RMSEn is greater than $20 \%$ and less than $30 \%$, and poor if the normalized RMSE is greater than 30\% [30]. Paired t-tests and linear regression analysis were also used to assess the goodness-of-fit between the observed and simulated results. If the P-value $(\mathrm{P}(\mathrm{t}))$ from the paired t-test was greater than 0.05 , it was concluded that no significant differences existed between the measured and simulated values.

\section{Results and Discussion}

Water management of rice genotype data from 2017 was used for calibration of the model and data from 2018 was used for validation of the model. Then the model was implemented and the biological and grain yield from simulation was compared with assessing amount based on statistical indices.

\section{Grain Yield}

Assessing parameters of the model ability in predicting the amount rice grain yield were shown in the Table 2. Statistical parameters used for every rice genotype are different rice grain. The irrigation treatment of RMSE for predicting grain yield is in the range from 267 to $484 \mathrm{~kg} \mathrm{ha}^{-1}$ and RMSEn in the range of 6 to 8 percent was obtained. According to statistics, modeling of grain yield is good and there is an appropriate adjustment between simulating and observed items. The resulted from the regression between simulated and assessed grain yield for rice genotype in irrigation treatment showed that the coefficient of determination $\left(\mathrm{R}^{2}\right)$ is more than $0.93 \%$. The high amount of $\mathrm{R}^{2}$ is an expressive parameter for showing little dispersion of data. The results of t-test showed that the simulated grain yield of this model in water management for rice genotypes is similar to assessed grain yield due to having more than 0.05 at $95 \%$ of probability level (Table 2, Fig. 1).
The assessed grain yield of rice genotypes was in the irrigation treatment in 2017 in the range of 3555 to $7754 \mathrm{~kg} \mathrm{ha}^{-1}$ while the grain yield of rice genotype from model was estimated in the range of 3699 to $8004 \mathrm{~kg}$ $\mathrm{ha}^{-1}$ and the relative error in predicting grain yield in the treatment situation of is between -5 to +15 percent (Table 6). The minimum relative error in predicting grain yield in irrigation treatments with 11 days alternate is Bahar genotype and the maximum relative error of irrigation treatment with 8 days alternate was also Bahar genotype. The results showed that the model predicts the grain yield by mean error of 5 percent and the model has the ability of simulating the effect of irrigation treatment on rice genotype.
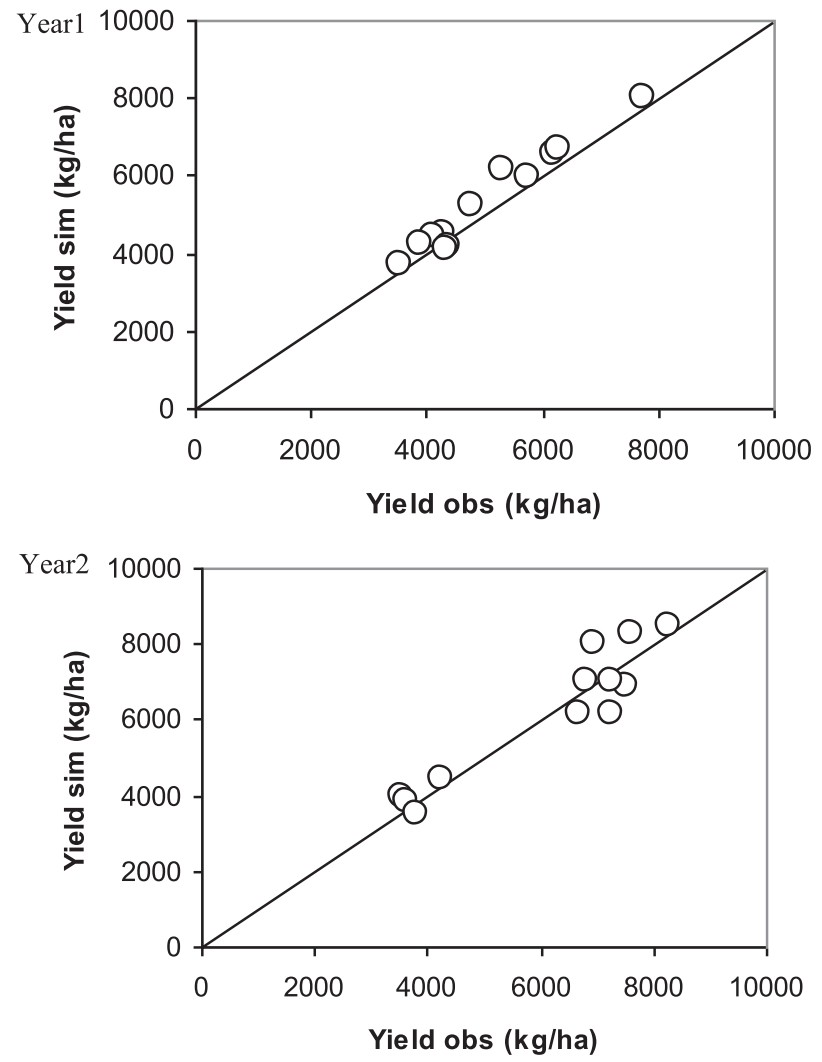

Fig. 1. Yield simulation vs yield observed during $1^{\text {st }}$ and $2^{\text {nd }}$ years. 
Table 3. Evaluating the AquaCrop model simulation results under calibration conditions, 2017.

\begin{tabular}{|c|c|c|c|c|c|c|c|}
\hline Genotypes & $\mathrm{N}$ & $\mathrm{X}_{\mathrm{obs}}$ & $\mathrm{X}_{\text {sim }}$ & $\mathrm{RMSE}$ & $\mathrm{RMSE}_{\mathrm{n}}(\%)$ & $\mathrm{P}(\mathrm{t})$ & $\mathrm{R}^{2}$ \\
\hline Grain yield & 12 & 5053 & 5311 & 366 & 7 & 0.31 & 0.96 \\
\hline Biological yield & 12 & 12298 & 11375 & 1312 & 11 & 0.19 & 0.86 \\
\hline
\end{tabular}

$\mathrm{X}_{\mathrm{obs}}$ : mean measured values, $\mathrm{X}_{\mathrm{sim}}$ : mean simulated values, RMSE: Root Mean Squared Error, RMSE $\mathrm{n}$ : Normalized Root Mean Squares Error

The parameters used to assess the model ability in predicting grain yield in the second year of experiment (validation) are shown in the Table 4. The results indicated that the RMSEn of rice genotypes is reached in the range of 8 to 9 , according to these statistical parameters, the modeling of grain yield is in good condition. The results from linear regression between simulated and assessed rice genotypes show that the $\mathrm{R} 2$ is more than $0.78 \%$. It is somehow similar to calibration conditions, and shows the appropriateness of model in the simulating grain yield in the second year of experiment. The results of t-test also show that the simulated grain yield of this model in water management for rice genotypes is similar to assessed grain yield because of having more than 0.05 at $95 \%$ of probability level (Table 4).

The grain yield of rice genotype in irrigation managements were in the range of 3550 to $8292 \mathrm{~kg} \mathrm{ha}^{-1}$ while the grain yield in model was estimated under the range of 3505 to $8473 \mathrm{~kg} \mathrm{ha}^{-1}$ and the relative error in predicting grain yield in irrigation management was -15 to 16 percent (Table 6 ). The minimum relative error in predicting grain yield in irrigation with 11 days interval is Dorfak genotype and the maximum relative error in irrigation with 8 days interval was Bahar genotype. The main reason of this variation in the accuracy of predicting grain yield based on different managements was due to various reasons such as the lack of appropriate mathematical models for using in AquaCrop model and error in parameters measurement $[32,33]$.

The data assessment demonstrates that the maximum yields in all genotypes were observed under flood irrigation. Flood irrigation provides suitable conditions for rice in various phases of growth while under irrigation interval conditions, most of characteristics related to yield and yield components show relative decreases because of water deficiency. Tarahomi et al. (2010) expressed that water stress resulting from nonflood irrigation causes the decrease of rice biological yield and yield because of preventing translocation of nutrition and reduction of photosynthesis [31]. According to the results, the normal error in the validation and calibration phases is 6 to 8 percent and 8 to 9 percent respectively and modeling of grain yield was calculated excellent. The maximum relative error of rich achievement in both of validation and calibration phases in irrigation with 8 days interval was in Bahar genotype and the minimum relative error of poor achievement in both of validation and calibration phases in irrigation with 11 days interval was in Dorfak and Bahar genotypes.

Changing the water management from flood irrigation to nonflood irrigation leads to decrease of actual yield, although the difference is not the same and the actual decrease depend on genotype. Bahar genotype had the maximum decrease in yield under irrigation management condition of 11 days interval and it was about $32 \%$. The model also simulates the yield in interval irrigated conditions less than flood irrigation in all genotypes of rice. By changing of irrigation interval, the model simulated yield was less than flood irrigation. Under irrigation conditions of 5, 8 and 11 days interval, the actual yield reduced by 10, 18 and 21 percent respectively and the simulated model showed the similar trend of yield decrease with 6, 11 and 27 percent. Ultimately, the AquaCrop model calculated

Table 4. Evaluating the AquaCrop model simulation results under calibration conditions, 2018.

\begin{tabular}{|c|c|c|c|c|c|c|c|c|}
\hline Genotypes & Genotypes & $\mathrm{N}$ & $\mathrm{X}_{\mathrm{obs}}$ & $\mathrm{X}_{\text {sim }}$ & $\mathrm{RMSE}$ & $\mathrm{RMSE}_{\mathrm{n}}(\%)$ & $\mathrm{P}(\mathrm{t})$ & $\mathrm{R}^{2}$ \\
\hline \multirow{2}{*}{ Ali kazemi } & Grain yield & 4 & 3806 & 3940 & 297 & 8 & 0.31 & 0.83 \\
\cline { 2 - 11 } & Biological yield & 4 & 9470 & 9076 & 629 & 7 & 0.29 & 0.67 \\
\hline \multirow{3}{*}{ Dorfak } & Grain yield & 4 & 7216 & 6772 & 668 & 9 & 0.07 & 0.78 \\
\cline { 2 - 12 } & Biological yield & 4 & 12577 & 14035 & 1781 & 14 & 0.08 & 0.84 \\
\hline \multirow{2}{*}{ Bahar } & Grain yield & 4 & 7373 & 7733 & 689 & 9 & 0.30 & 0.90 \\
\cline { 2 - 11 } & Biological yield & 4 & 14171 & 16054 & 2187 & 15 & 0.10 & 0.69 \\
\hline
\end{tabular}

$\mathrm{X}_{\mathrm{obs}}$ : mean measured values, $\mathrm{X}_{\mathrm{sim}}$ : mean simulated values, RMSE: Root Mean Squared Error, RMSE $\mathrm{n}_{\mathrm{n}}$ Normalized Root Mean Squares Error 
Table 5. Evaluating the AquaCrop model simulation results under calibration conditions, 2018.

\begin{tabular}{|c|c|c|c|c|c|c|c|}
\hline Genotypes & $\mathrm{N}$ & $\mathrm{X}_{\text {obs }}$ & $\mathrm{X}_{\text {sim }}$ & RMSE & RMSE $_{\mathrm{n}}(\%)$ & $\mathrm{P}(\mathrm{t})$ & $\mathrm{R}^{2}$ \\
\hline Grain yield & 12 & 6132 & 6148 & 580 & 9 & 0.49 & 0.89 \\
\hline Biological yield & 12 & 12073 & 13055 & 1668 & 14 & 0.20 & 0.87 \\
\hline
\end{tabular}

$\mathrm{X}_{\mathrm{obb}}$ : mean measured values, $\mathrm{X}_{\mathrm{sim}}$ : mean simulated values, RMSE: Root Mean Squared Error, RMSE $\mathrm{n}$ : Normalized Root Mean Squares Error

rich achievement because of positive mean error in validation and calibration phases.

Kumar et al. (2014) after assessing the AquaCrop model in Delhi, India for four genotypes of wheat and four levels of salinity level for irrigation water reported that the model has an acceptable accuracy in simulating biological yield [24]. Zeleke and Nendel evaluated AquaCrop for the two wheat cultivars under rainfed and irrigated in Australia. The root-mean-square error (RMSE) for grain yield and aboveground biomass was 0.293 and $2.2 \mathrm{t} \mathrm{ha}^{-1}$, respectively [32].

\section{Biological Yield}

The results of statistical parameters related to total biological yield used for model assessing has been presented in Table 2. The RMSE concerning the prediction of the grain yield is in the range of 294 to $1612 \mathrm{~kg} \mathrm{ha}^{-1}$ and RMSEn is reached in range of 3 to 13 percent. According to these statistics, the model could make excellent genotype of model and there is a good adaptation among simulated and observed yield. The results from linear regression between simulated and assessed biological yield for rice genotype show that the coefficient of determination $\left(\mathrm{R}^{2}\right)$ is more than $0.86 \%$. The results of t-test showed simulated biological yield of model under irrigation conditions for rice genotype is more than 0.05 , and it showed that the similarity between simulating and assessing at the probability level of $95 \%$ (Table 2, Fig. 2).

The assessed biological yield of rice genotypes in irrigation condition was in range of 8267 to $17624 \mathrm{~kg} \mathrm{ha}^{-1}$ while the biological yield reached from the model was estimated in the range of 8674 to $16375 \mathrm{~kg} \mathrm{ha}^{-1}$ and the relative error in predicting of biological yield in irrigation condition was -22 to 5 percent. The maximum relative error in the biological yield prediction in the irrigation with 11 days interval observed in Ali Kazemi genotype and the minimum relative error in the irrigation with 11 days interval observed in Dorfak genotype. The results have shown that the percent of error approximately was -8 (Table 7 ).

The parameters estimated by calibration of model were used for validation and evaluation of AquaCrop model. The statistics used to evaluate the model performance are shown in Table 7. The RMSE in predicting the biological yield is reached in range of 629 to $2187 \mathrm{~kg} \mathrm{ha}^{-1}$ and RMSEn is reached in range

Table 6. Simulated and observed grain yield values of rice genotypes and relative error percentage of the model simulation.

\begin{tabular}{|c|c|c|c|c|c|c|c|}
\hline \multirow[b]{2}{*}{ Genotypes } & \multirow[b]{2}{*}{ Irrigation management } & \multicolumn{3}{|c|}{2017} & \multicolumn{3}{|c|}{2018} \\
\hline & & $\begin{array}{c}\text { Observed } \\
\left(\mathrm{kg} \mathrm{ha}^{-1}\right)\end{array}$ & $\begin{array}{c}\text { Simulated } \\
\left(\mathrm{kg} \mathrm{ha}^{-1}\right)\end{array}$ & $\begin{array}{l}\text { Relative } \\
\text { error (\%) }\end{array}$ & $\begin{array}{c}\text { Observed } \\
\left(\mathrm{kg} \mathrm{ha}^{-1}\right)\end{array}$ & $\begin{array}{c}\text { Simulated } \\
\left(\mathrm{kg} \mathrm{ha}^{-1}\right)\end{array}$ & $\begin{array}{l}\text { Relative } \\
\text { error }(\%)\end{array}$ \\
\hline \multirow{4}{*}{ Ali kazemi } & Flood & 4289 & 4492 & 5 & 4267 & 4422 & 4 \\
\hline & Irrigation 5 days alternate & 4123 & 4426 & 7 & 3550 & 3968 & 12 \\
\hline & Irrigation 8 days alternate & 3878 & 4240 & 9 & 3607 & 3863 & 7 \\
\hline & Irrigation 11 days alternate & 3555 & 3699 & 4 & 3801 & 3505 & -8 \\
\hline \multirow{4}{*}{ Dorfak } & Flood & 6209 & 6529 & 5 & 7538 & 6879 & -9 \\
\hline & Irrigation 5 days alternate & 5737 & 5966 & 4 & 7266 & 7029 & -3 \\
\hline & Irrigation 8 days alternate & 4789 & 5232 & 9 & 6800 & 7033 & 3 \\
\hline & Irrigation 11 days alternate & 4389 & 4200 & -4 & 7258 & 6145 & -15 \\
\hline \multirow{5}{*}{ Bahar } & Flood & 7754 & 8004 & 3 & 8292 & 8473 & 2 \\
\hline & Irrigation 5 days alternate & 6282 & 6697 & 7 & 7590 & 8258 & 9 \\
\hline & Irrigation 8 days alternate & 5312 & 6128 & 15 & 6946 & 8030 & 16 \\
\hline & Irrigation 11 days alternate & 4318 & 4122 & -5 & 6665 & 6170 & -7 \\
\hline & Average & 5053 & 5311 & 5 & 6132 & 6148 & 0 \\
\hline
\end{tabular}



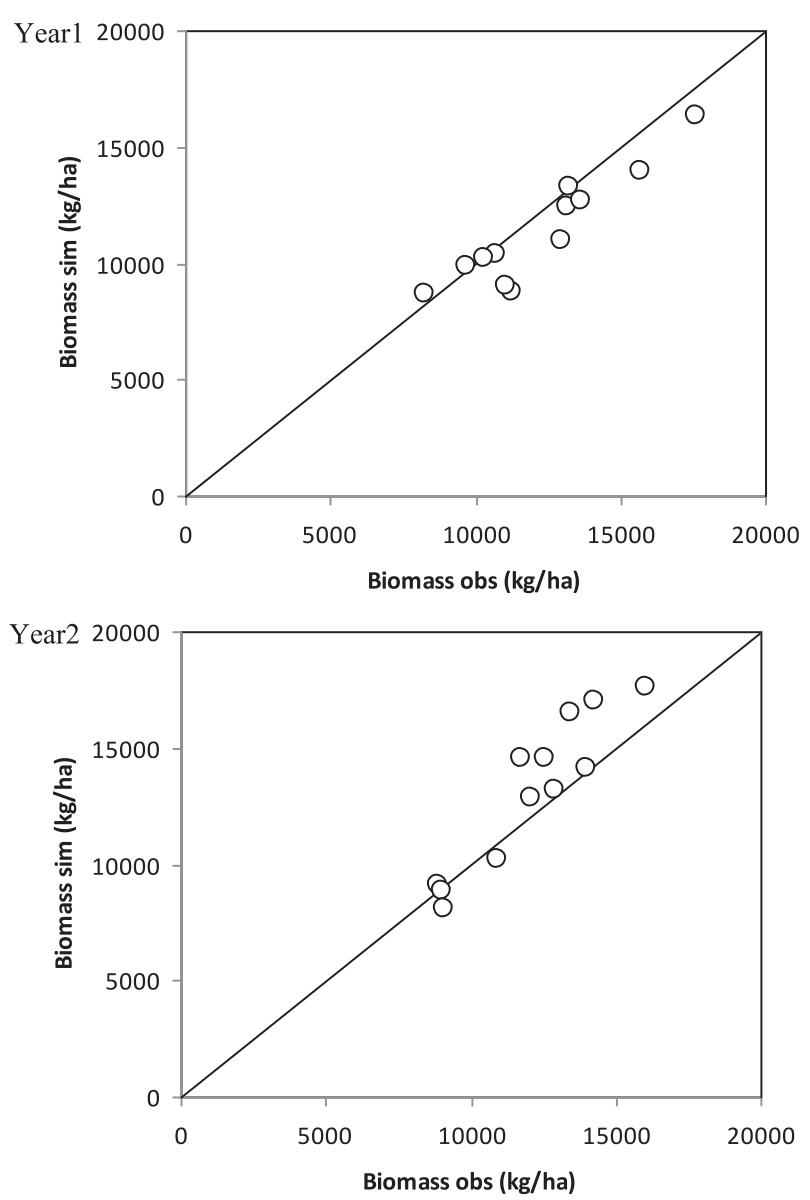

Fig. 2. Biological Yield simulation vs Biological yield observed during $1^{\text {st }}$ and $2^{\text {nd }}$ years. of 7 to 15 percent. The results from linear regression between simulated and assessed biological yield for rice genotypes showed that the coefficient of determination $\left(\mathrm{R}^{2}\right)$ is more than $0.67 \%$. The results of t-test showed that the simulated biological yield of model under irrigation conditions for rice genotype is more than 0.05 , and it showed that the similarity between simulating and assessing located within the probability level of 95\% (Table 4).

The assessed biological yield for rice genotypes in irrigation management was in the range of 8875 to $16070 \mathrm{~kg} \mathrm{ha}^{-1}$. While the biological yield of rice genotypes was estimated in the range of 8065 to $17581 \mathrm{~kg} \mathrm{ha}^{-1}$. The relative error in predicting total biological in irrigation management conditions was from -11 to 24 percent (Table 7 ) and the relative error was assessed approximately 8 percent. In other words, the maximum biological yield was reached under flood irrigation conditions in all rice genotypes and by increasing water stress, the biological yield has shown decreasing process in all genotypes; hence the assessed amount in the field and predicting amount by the model prove this claim.

Andarzian et al. (2011) assessed AquaCrop model for wheat crop using various scenarios of less irrigation (at various phases of plant growth and practical water depth). The results of their study showed that the model could simulate the biological and grain yield with satisfactory results [33].

Table 7. Simulated and observed biological yield values of rice cultivars and relative error percentage of the model simulation.

\begin{tabular}{|c|c|c|c|c|c|c|c|}
\hline \multirow{3}{*}{ Genotypes } & Irrigation management & \multicolumn{3}{|c|}{2017} & \multicolumn{4}{c|}{2018} \\
\cline { 3 - 8 } & Flood & $\begin{array}{c}\text { Observed } \\
\left(\mathrm{kg} \mathrm{ha}^{-1}\right)\end{array}$ & $\begin{array}{c}\text { Simulated } \\
\left(\mathrm{kg} \mathrm{ha}^{-1}\right)\end{array}$ & $\begin{array}{c}\text { Relative } \\
\text { error (\%) }\end{array}$ & $\begin{array}{c}\text { Observed } \\
\left(\mathrm{kg} \mathrm{ha}^{-1}\right)\end{array}$ & $\begin{array}{c}\text { Simulated } \\
\left(\mathrm{kg} \mathrm{ha}^{-1}\right)\end{array}$ & $\begin{array}{c}\text { Relative } \\
\text { error }(\%)\end{array}$ \\
\hline \multirow{5}{*}{ Ali kazemi } & 10722 & 10341 & -4 & 10941 & 10212 & -7 \\
\cline { 2 - 9 } & Irrigation 5 days alternate & 10308 & 10182 & -1 & 8875 & 9136 & 3 \\
\cline { 2 - 9 } & Irrigation 8 days alternate & 9694 & 9830 & 1 & 9017 & 8891 & -1 \\
\cline { 2 - 9 } & Irrigation 11 days alternate & 8267 & 8674 & 5 & 9049 & 8065 & -11 \\
\hline \multirow{5}{*}{ Dorfak } & Flood & 13212 & 13281 & 1 & 13960 & 14169 & 1 \\
\cline { 2 - 9 } & Irrigation 5 days alternate & 13159 & 12421 & -6 & 12527 & 14542 & 16 \\
\cline { 2 - 9 } & Irrigation 8 days alternate & 12942 & 10978 & -15 & 11724 & 14546 & 24 \\
\cline { 2 - 9 } & Irrigation 11 days alternate & 11254 & 8806 & -22 & 12097 & 12883 & 6 \\
\hline \multirow{5}{*}{ Bahar } & Flood & 17624 & 16375 & -7 & 16070 & 17581 & 9 \\
\cline { 2 - 9 } & Irrigation 5 days alternate & 15705 & 13921 & -11 & 14235 & 16981 & 19 \\
\cline { 2 - 9 } & Irrigation 8 days alternate & 13620 & 12686 & -7 & 13462 & 16503 & 23 \\
\cline { 2 - 9 } & Irrigation 11 days alternate & 11072 & 9001 & -19 & 12917 & 13151 & 2 \\
\hline & Average & 12298 & 11375 & -8 & 12073 & 13055 & 8 \\
\hline
\end{tabular}




\section{Conclusions}

Results of simulation of grain yield and biological yield of rice cultivars in the first year of experiment showed that the model with average RMSEn for predicting grain yield and biological yield for rice cultivars were 7 and $11 \%$, respectively. The results of simulation of grain yield and biological yield of rice cultivars in the second year of experiment showed that the model with RMSEn average for predicting grain yield and biological yield for rice cultivars were 14 and $9 \%$, respectively, and the R2 above 0.87 And 0.89 had good accuracy in predicting grain yield and biological yield of rice cultivars. The results also showed that the AquaCrop model estimated the error of predicting grain and biological yield in three rice genotypes of northern Iran was less than 5 percent which demonstrates an excellent accuracy of the model in predicting grain yield and biological yield. AquaCrop model in comparison with other models require smaller number of input data and parameters for simulating plants reactions to water and can be used for most of agricultural and farming crops in the world. According to these results, this model may be recommended for the above mentioned genotype in relation to irrigation planning in the region.

\section{Conflict of Interest}

The authors declare no conflict of interest.

\section{References}

1. AHMAD S., AHMAD A., Ali H., HUSSAIN A., GARCIA Y GARCIA A., KHAN M.A., ZIA-UL-HAQ M., HASANUZZAMAN M., HOOGENBOOM G. Application of the CSM-CERES-Rice model for evaluation of plant density and irrigation management of transplanted rice for an irrigated semiarid environment. Irrigation Science, 31 (3), 491, 2013.

2. FAO. FAO statistical year book. Food and Agriculture Organization, Rome, 2012.

3. FAO, Rice Market Monitor. Volume XVIII - Issue No. 4, December, 2015.

4. AMIRI E., REZAEI M. Evaluation of Water-Nitrogen Schemes for Rice in Iran, Using ORYZA2000 Model. Communications in soil science and plant analysis, 41 (20), 2459, 2009.

5. WAILES E.J., CHAVEZ E.C. World Rice Outlook. International Rice Baseline with Deterministic and Stochastic Projections, 2012-2021. Aaes. Agric. Bus. U. Ark., Division of Agriculture Staff. 81, 2012.

6. PRASAD S., SINGH M.P., YADAV R.K. Physio-chemical changes in rice varieties under drought stress condition. Plant Archives, 12 (1), 63, 2012.

7. KAWASAKI J., HERATH S. Impact assessment of climate change on rice production in Khon Kaen Province, Thailand Journal. ISSAAS, 17, 14, 2011.

8. DARYANTO S., WANG L., JACINTHE P.A. Global Synthesis of Drought Effects on Maize and Wheat Production. PLoS ONE, 11 (5), 1, 2016.
9. BOUMAN, B. A. M. and TUONG, T. P. Field water management to save water and increase its productivity in irrigated rice. Agricultural Water Management, 49 (1), 11, 2001.

10. CARMELITA M., ALBERTO R., WASSMANN R., HIRANO T., MIYATA A., HATANO R., KUMAR A. PADRE A., AMANTE M. Comparisons of energy balance and evapotranspiration between flooded and aerobic rice fields in the Philippines. Agricultural Water Management, 98 (9), 1417, 2011.

11. KATOH M., IWATA A., SHAKU I., NAKAJIMA Y., MATSUYA K., KIMURA M. Impact of water percolation on nutrient leaching from an irrigated paddy field in Japan. Soil Use and Management, 19 (4), 298, 2003.

12. AMIRI E., RAZAVIPOUR T., FARID A., BANNAYAN M. Effects of Crop Density and Irrigation Management on Water Productivity of Rice Production in Northern Iran: Field and Modeling Approach, Communications in Soil Science and Plant Analysis, 42 (17), 2085, 2011.

13. JAPAN INTERNATIONAL COOPERATION AGENCY. The study on integrated water resources management for Sefidroud river basin in the Islamic Republic of Iran. Final report. CTI Engineering International Co., Ltd. Water Resources Management Company. The Ministry of Energy, the Islamic Republic of Iran, 2012.

14. RAN H., KANG S., LI F., TONG A., LING, DING A, RISHENG, DU T., LI S., ZHANG X. Performance of AquaCrop and SIMDualKc models in evapotranspiration partitioning on full and deficit irrigated maize for seed production under plastic film-mulch in an arid region of China. Agric. Syst. 151, 20, 2017.

15. HAWKESFORD M.J., GRIFFITHS, S. Exploiting genetic variation in nitrogen use efficiency for cereal crop improvement. Curr Opin Plant Biol, 49, 35, 2019.

16. BEHERA S.K., PANDA R.K. Integrated management of irrigation water and fertilizers for wheat crop using field experiments and simulation modeling. Agricultural Water Management, 96 (11), 1532, 2009.

17. STEDUTO P., HSIAO T.C., RAES D., FERERES E. AquaCrop. The FAO crop model to predict yield response to water. Agronomy Journal, 101 (3), 426, 2009.

18. RAES D., STEDUTO P., HSIAO T.C., FERERES E. AquaCrop-The FAO crop model to predict yield response to water: II Main algorithms and soft ware description. Agronomy Journal, 101 (3), 438, 2009.

19. MALIK A., SHAKIR A.S., AJMAL M., KHAN M.J., KHAN T.A. Assessment of AquaCrop model in simulating sugar beet canopy cover, biological yield and root yield under different irrigation and field management practices in semi-arid regions of Pakistan. Water Resources Management, 31 (13), 4275, 2017

20. AKUMAGA U., TARHULE A., YUSUF A. A. Validation and testing of the FAO AquaCrop model under different levels of nitrogen fertilizer on rainfed maize in Nigeria, West Africa. Agricultural and Forest Meteorology, 232, 225, 2017.

21. MONTOYA F., CAMARGO D., ORTEGA J.F., CORCOLES J.I., DOMINGUEZ A. Evaluation of Aquacrop model for a potato crop under different irrigation conditions. Agricultural Water Management, 164 (2), 267, 2016.

22. TOUMI J., ER-RAKI S., EZZAHAR J., KHABBA S., JARLAN L., CHEHBOUNI A. Performance assessment of AquaCrop model for estimating evapotranspiration, soil water content and grain yield of winter wheat in Tensift Al Haouz (Morocco): Application to irrigation 
management. Agricultural Water Management, 163 (1), 219, 2016.

23. MABHAUDHI T., MODI A.T., BELETSE Y.G. Parameterisation and evaluation of the FAOAquaCrop model for a South African taro (Colocasia esculenta L. Schott) landrace. Agricultural and Forest Meteorology, 192-193, 132, 2014.

24. KUMAR A., SARANGI P., SINGH A., PARIHAR S.S. Evaluation of AquaCrop model in predicting wheat yield and water productivity under irrigated saline regimes. Irrig.Drain, 63 (4), 474, 2014.

25. KHALILI N., DAVARY K., ALIZADEH A., KAFI M., ANSARI H. Simulation of rainfed wheat yield using AquaCrop model, case study: Sisab. Rainfed Researches Station, Northern Khorasan. Journal of Water and Soil, 28 (5), 930, 2014.

26. ALLEN R.G., PEREIRA L.S., RAES D., SMITH M. Crop evapotranspiration. Irrigation and Drainage Paper, No. 56, FAO, Rome, Italy. 1998.

27. DOORENBOS J., KASSAM A.H. Yield response to water. Irrigation and Drainage Paper no 33. FAO, Rome, Italy. 1979.
28. RAES D., STEDUTO P., HSIAO T.C. and FERERES, E. Reference Manual AquaCrop, FAO, Land and Water Division, Rome, Italy, 2012.

29. BOUMAN B.A.M., VAN LAAR H.H. Description and evaluation of the rice growth model ORYZA2000 under nitrogen-limited conditions. Agric Syst, 87 (3), 249, 2006.

30. JAMIESON P.D., PORTER J.R., WILSON D.R. A test of the computer simulation model ARC-WHEAT1 on wheat crops grown in New Zealand. Field Crops Res, 27 (4), 337, 1991.

31. TARAHOMI G., LAHUTI M., ABBASI F. Effects of drought stress on changes in soluble carbohydrates, chlorophyll and potassium in Salvia lerifol Benth. j. Bio. Sci. I. A. U. Z, 3 (2), 1, 2010.

32. ZELEKE K.T. AquaCrop calibration and validation for faba bean (Vicia faba L.) under different agronomic managements. Agron., 9 (6), 320, 1, 2019.

33. ANDARZIAN B., BANNAYAN M., STEDUTO P., MAZRAEH H., BARATI M.E., BARATI M.A., RAHNAMA A. Validation and testing of the AquaCrop model under full and deficit irrigated wheat production in Iran. Agricultural Water Management, 100 (1), 1, 2011. 
